\title{
Herbarium specimens as tools to assess the impact of large herbivores on plant species.
}

\begin{tabular}{|r|l|}
\hline Journal: & Botany \\
\hline Manuscript ID & cjb-2016-0206.R1 \\
\hline Danuscript Type: & Article \\
\hline Complete List of Authors: & $\begin{array}{l}\text { Beauvais, Marie-Pierre; Université de Montréal, Institut de recherche en } \\
\text { biologie végétale and Jardin botanique de Montréal } \\
\text { Pellerin, Stéphanie; Université de Montréal, Institut de recherche en } \\
\text { biologie végétale and Jardin botanique de Montréal } \\
\text { Dubé, Jean; Université Laval, École supérieure d'aménagement du } \\
\text { territoire et de développement régional } \\
\text { Lavoie, Claude; Université Laval, École supérieure d'aménagement du } \\
\text { territoire et de développement régional }\end{array}$ \\
\hline Keyword: & $\begin{array}{l}\text { herbarium specimen, Odocoileus virginianus, overbrowsing, Trillium } \\
\text { grandiflorum, white-tailed deer }\end{array}$ \\
\hline \multicolumn{2}{|l}{} \\
\hline
\end{tabular}




\section{Herbarium specimens as tools to assess the impact of large herbivores on plant species}

Marie-Pierre Beauvais, Stéphanie Pellerin, Jean Dubé and Claude Lavoie

M.-P. Beauvais and S. Pellerin. Institut de recherche en biologie végétale and Jardin botanique de Montréal, Université de Montréal, 4101 Sherbrooke est, Montréal, QC H1X 2B2, Canada (e-mail: M.P.B: marie-pierre.beauvais@umontreal.ca; S.P.: stephanie.pellerin.1@umontreal.ca).

J. Dubé and C. Lavoie. École supérieure d'aménagement du territoire et de développement régional, Université Laval, Québec, QC G1A 0V6, Canada (e-mail: J.D.: jean.dube@esad.ulaval.ca; C.L.: claude.lavoie@esad.ulaval.ca).

Corresponding author: Claude Lavoie, École supérieure d’aménagement du territoire et de développement régional, Université Laval, Québec, QC G1A 0V6, Canada. Tel.: 1-418-656-2131 ext. 5375; Fax: 1-418-656-2018. E-mail: claude.lavoie@esad.ulaval.ca. 
Abstract: Herbarium specimens can be used to reconstruct spatiotemporal changes in plant morphology caused by environmental pressures. The reliability of herbarium-derived data requires evaluation, because specimen collection is subject to biases. We used herbarium and field data to investigate the impact of large herbivore browsing on the size of a forb. White trillium (Trillium grandiflorum (Michaux) Salisbury) was studied because the impacts of white-tailed deer (Odocoileus virginianus Zimmermann) browsing on this species are well-known. A total of 692 herbarium specimens collected in Quebec (Canada) were used to evaluate leaf area. Leaf area values of herbarium specimens were compared to those of modern $(2013,2014)$ specimens collected in sites with $>8$ deer per $\mathrm{km}^{2}$ or without deer. Flowering individuals in modern sites with deer had a significantly lower leaf area than herbarium specimens and modern specimens collected in sites without deer. The distribution of white trillium individuals in deer sites was also skewed towards plants with a smaller leaf area. Herbarium specimens may offer unique and inexpensive data, compared to methods traditionally used to assess the impacts of herbivores on plants such as exclosures or clipping experiments. Unfortunately, this rich data source is seriously jeopardized by the downtrend in specimen collecting.

Key words: herbarium specimen, Odocoileus virginianus, overbrowsing, Trillium grandiflorum, whitetailed deer, white trillium. 
Résumé : Les spécimens d'herbier peuvent être utilisés pour analyser des changements spatiotemporels dans la morphologie des plantes en réponse à des phénomènes environnementaux. La qualité des données doit toutefois être vérifiée, car la récolte des spécimens est sujette à plusieurs biais. Nous avons utilisé des spécimens d'herbier et des données de terrain pour analyser l'effet du surbroutement sur la taille d'une plante herbacée. Le trille blanc (Trillium grandiflorum (Michaux) Salisbury) a été choisi pour cette étude car les conséquences du broutement des cerfs de Virginie (Odocoileus virginianus Zimmermann) sur cette espèce sont bien connues. La surface foliaire de 692 spécimens d'herbier récoltés au Québec (Canada) a été calculée puis comparée à celle de spécimens modernes $(2013,2014)$ échantillonnés dans des sites avec une densité de cerfs $>8$ individus au $\mathrm{km}^{2}$ ou sans cerf. Les trilles modernes en fleur dans les sites avec cerfs avaient une surface foliaire significativement plus petite que celle des spécimens d'herbier et des plants des sites sans cerf. La distribution de taille des trilles dans les sites avec cerfs était asymétrique, avec une plus forte proportion de plants de petite taille. Les spécimens d'herbier peuvent constituer une source unique et peu coûteuse de données - en comparaison avec des sources plus traditionnelles issues des exclos ou d'expériences de broutement artificiel - pour mesurer l'effet des herbivores sur les plantes. Malheureusement, cette source est en train de se tarir faute de récolte de nouveaux spécimens.

Mots-clés : cerf de Virginie, Odocoileus virginianus, spécimen d'herbier, surbroutement, trille blanc, Trillium grandiflorum. 


\section{Introduction}

Over the last century, populations of large ungulates have greatly increased in several regions of the world due to strict hunting regulations, a reduction of the number of natural predators, and an increased food supply associated with land use change (Côté et al. 2004). Overbrowsing by ungulates frequently induces major changes of forest composition and structure, and is consequently becoming a serious conservation issue (Côté et al. 2004; Begley-Miller et al. 2014). For example, in temperate and boreal forests of northeastern North America, white-tailed deer (Odocoileus virginianus Zimmerman) have prevented the regeneration of many shrub and tree species (Hidding et al. 2012; Nuttle et al. 2013), and have caused the local disappearance of preferred food species and the dominance of avoided or browsing-resilient plants (Horsley et al. 2003; Webster et al. 2005; Begley-Miller et al. 2014).

Although the short-term effects of overbrowsing on forest composition are relatively well known, the long-term impacts of intense deer herbivory on plant population dynamics are less understood (McGraw and Furedi 2005; Webster et al. 2005; Knight et al. 2008; Collard et al. 2010; Webster and Jenkins 2014; Pendergast et al. 2016). Deer can directly threaten growth, reproduction and survival of plants by removing leaves, buds, shoots, flowers and fruits (Côté et al. 2004), which may in turn negatively impact fitness. For example, studies conducted on white trillium (Trillium grandiflorum (Michaux) Salisbury) in eastern North America showed that repeated deer browsing reduces the proportion of flowering individuals and plant leaf area and height over time (Anderson 1994; Augustine and Frelich 1998; Rooney and Waller 2001; Knight 2003; Knight et al. 2009). More specifically, intense and repeated browsing skews the population structure toward smaller plants (Anderson 1994; Augustine and Frelich 1998), and consequently alters their reproductive success, as small individuals produce fewer ovules (Knight 2003). Chronic overbrowsing could eventually cause the local extinction of this species (Knight et al. 2009). 
Obtaining a spatial and historical perspective on the long-term impacts of overbrowsing is difficult because vegetation studies are generally local and rarely span more than a few years. On the other hand, plant specimens collected over several decades and preserved in herbaria may provide the data needed to obtain such a perspective (Lavoie 2013). In this respect, herbarium specimens have successfully been used in a few studies to document plant morphological changes over time, and estimate the possible consequences on fitness (McGraw 2001; Law and Salick 2005; Guerin et al. 2012; Leger 2013). For instance, Law and Salick (2005) showed, using museum collections and modern specimens, that sustained human harvesting over $100 \mathrm{yr}$ of a medicinal Tibetan plant (Saussurea laniceps Handel-Mazzetti) resulted in a rapid evolution toward smaller individuals. Herbarium data also showed that large-scale harvesting of American ginseng (Panax quinquefolius Linnaeus) in North America has caused significant plant size decline since the beginning of the 20th century (McGraw 2001). In both cases, these morphological changes are increasing the vulnerability of these plants to extinction.

Herbarium collections offer a tool for detecting spatiotemporal morphological changes resulting from natural and anthropogenic disturbances. However, this tool requires validation because herbarium specimen collection may suffer from several biases associated with opportunistic (nonrandomized) sampling strategies and the preference of collectors for healthy individuals (Delisle et al. 2003; Lavoie 2013). In this study, we used herbarium specimens to investigate, for the first time (to our knowledge), the effects of browsing by a large herbivore on forb size. More precisely, we compared the size of herbarium specimens to that of modern specimens sampled in both grazed and ungrazed forests. We hypothesized that herbarium specimens and modern specimens in sites without deer are significantly larger than specimens in sites with dense deer populations. 


\section{Methods}

\section{Studied species}

White trillium was selected for this study because the effects of deer browsing on this species are well-known, making it an ideal candidate to validate the use of herbarium specimens for detecting morphological changes associated with browsing over decades. White trillium is a non-clonal, longlived, perennial forb that grows in the understory of deciduous forests throughout eastern North America (Case and Case 1997; Knight 2003). Reproductive plants are characterized by the presence of a single stem, rarely two, supporting a whorl of three leaves and one hermaphroditic white flower producing a single fruit (Knight 2003). Seeds are mainly dispersed by ants (Case and Case 1997; Kalisz et al. 1999). They produce small adventitious roots during the first year of growth, whereas the cotyledon emerges in the second year, and the first true leaf unfolds the third year (Hanzawa and Kalisz 1993; Knight et al. 2008). This species begins to reproduce after about $17 \mathrm{yr}$, but an individual can become dormant for one or several years (Hanzawa and Kalisz 1993; Knight 2003). In Quebec (Canada), where this study was conducted, most leaves appear late April, before the forest canopy leafs out. Flowering occurs from mid to late May. White-tailed deer preferentially consume large reproductive individuals, and consumption usually results in complete defoliation (Anderson 1994; Augustine and Frelich 1998; Knight 2003). Browsing stops growth, but few individuals die after a single consumption event, although browsed plants are more likely to retrogress to a vegetative stage the next spring (Knight 2003; Rooney and Gross 2003; Knight et al. 2009).

\section{Herbarium specimen sampling}

Herbarium specimens of white trillium collected in Quebec were requested from the four largest herbaria (> 137000 specimens) of the province (MT, MTMG, QFA, QUE) and from the two Canadian national herbaria (CAN, DAO), for a total of 794 trillium specimens. Only specimens with fully opened flowers, to control for life stage difference as well as biases in collection effort towards 
flowering individuals, and a precise sampling location and date were retained ( $n=692$; Fig. 1 and cjb-2016-0206.R1 Supplement 1). Additional information recorded was specimen number, habitat characteristics and name of collectors. Plant leaf area was calculated with the equation developed by Augustine and Frelich (1998) for the same trillium species: plant leaf area = leaf length $\times$ leaf width $\times 0.5 \times$ number of leaves (3). Leaf scans were not performed as the modern specimens used for comparison were located in protected areas, and their collection was prohibited. For each specimen, leaf length and width data were collected from one of the leaves randomly selected. Leaf area is highly correlated with other size-related traits of white trillium, such as leaf length, plant height and stem diameter, and is thus a good indicator of overall plant size (Rooney and Waller 2001).

\section{Herbarium specimens and temperature or bioclimatic data}

Leaf area of herbarium specimens can be influenced by the preference of collectors for certain size classes or healthiest individuals, a bias hard to correct, and by other factors such as temperature (Peppe et al. 2011), which fluctuates in space and time. An increased leaf area over time could result from warming temperatures associated with climate change (Guerin et al. 2012). The evolution of leaf area (minimum, median and maximum values) through time was compared to the evolution of temperatures in Southern Quebec. Most white trillium specimens $(n=597)$ were sampled on the Island of Montréal or on the Monteregian Hills region (Fig. 1); data from the meteorological stations of this region (or proximate to) with the longest climatic record (Drummondville, Les Cèdres, Montréal McGill University, Montréal Pierre-Elliott-Trudeau International Airport; Government of Canada 2016) were used. The number of growing degree-days $>0{ }^{\circ} \mathrm{C}(1$ January -31 May) was used in the model.

A regional climatic effect was also tested by grouping specimens according to their bioclimatic area, using the bioclimatic region classification of Grandtner (1966): (1) sugar maple (Acer saccharum Marshall) - bitternut hickory (Carya cordiformis (Wangenheim) K. Koch) region, 
(2) sugar maple - basswood (Tilia americana Linnaeus) region, and (3) sugar maple - yellow birch (Betula alleghaniensis Britton) region. Significant differences between groups would suggest that differences in leaf area are potentially climate-dependent. A site effect was also tested by grouping the specimens according to their location (Table 1), since most white trillium specimens $(n=597)$ were sampled in a relatively small number of locations of the sugar maple - bitternut hickory bioclimatic region, either in the Mont-Royal Park (Montréal), in other sites of the Island of Montréal, or on the Monteregian hills.

\section{Field sampling}

The modern white trillium population with clear evidence of overgrazing (Figs. 1 and 2) used in this study was located in the Mont-Saint-Bruno National Park (MSB), a 900 ha park established in 1985 near Montréal $\left(45^{\circ} 33^{\prime} \mathrm{N}, 73^{\circ} 19^{\prime} \mathrm{W}\right)$ to protect one of the nine Monteregian Hills of the St. Lawrence River Lowlands. The Saint-Bruno Mountain (maximum elevation: $218 \mathrm{~m}$ a.s.l) is covered by deciduous forests dominated by sugar maple, American beech (Fagus grandifolia Ehrhart) and bitternut hickory on mesic sites, and by sugar maple, eastern hemlock (Tsuga canadensis (Linnaeus) Carrière) and northern red oak (Quercus rubra Linnaeus) on well-drained slopes with thin soils (Gratton 1981). White-tailed deer were very rare in the park in 1972 (Huot 1973); populations have expanded since the mid-1980s, with densities reaching $>8$ individuals per $\mathrm{km}^{2}$ in the early 2000s (MSB, unpublished data). Populations of white trillium were scouted at MSB during the flowering period (9-15 May 2013; 14 May 2014). The hiking trail network in the park is extensive (30-km long) and gives access to all sectors. The leaf area of each flowering individual (all sites: $n=2064$ ) was calculated as for herbarium specimens.

Other populations (with and without deer) were sampled for comparison purposes (Fig. 1). The Fernand-Séguin Ecological Center (FSEC; $45^{\circ} 21^{\prime} \mathrm{N}, 73^{\circ} 47^{\prime} \mathrm{W}$ ), a 60 ha suburban park near Châteauguay (about $30 \mathrm{~km}$ from MSB), is potentially impacted by deer overbrowsing. According to the latest (1997, 2006 and 2008) aerial surveys in the vicinity of the park, deer density was about 
5 individuals per $\mathrm{km}^{2}$. However, in the Montréal region, deer density in forest stands is often greater than the estimated regional density since woodlots are frequently used as refuges by the animals (Huot and Lebel 2012). FSEC is covered by a sugar maple and bitternut hickory forest, and although deer are abundant, white trillium is still present. All flowering individuals present in 20 circular quadrats $\left(1 \mathrm{~m}^{2}\right)$ randomly located in the forest of FSEC were measured for leaf area (15 May 2014).

Natural forest sites with white trillium but without deer are rare in the Montréal area; the study sites were located in the Mont-Royal Park (MRP; $45^{\circ} 31^{\prime} \mathrm{N}, 73^{\circ} 36^{\prime} \mathrm{W}, 200$ ha) and the Montréal Botanical Garden (MBG; $45^{\circ} 33^{\prime} \mathrm{N}, 73^{\circ} 33^{\prime} \mathrm{W}, 75 \mathrm{ha}$ ). The MRP, located in the heart of the Island of Montréal, has the same geological origin as MSB (Monteregian hill; $233 \mathrm{~m}$ a.s.l.). Two MRP forest stands, both dominated by sugar maple and northern red oak, were sampled in 2014 (16 May). Two unmanaged forest stands in MBG, dominated by sugar maple, red ash (Fraxinus pennsylvanica Marshall) and white elm (Ulmus americana Linnaeus), were sampled in 2013 (15 May) and 2014 (17 May). These stands were sampled the same way as at FSEC. It should be noted that according to the maps of urban heat islands created for the Montréal region, the relative surface temperature of these urban parks during the warmest period of the summer (July-September, the only period for which data were available) is $15.9-18.7^{\circ} \mathrm{C}$, which is similar to that of recorded at MSB (15.9$17.6^{\circ} \mathrm{C}$; Centre d'enseignement et de recherche en foresterie de Sainte-Foy and Institut national de la santé publique du Québec 2012).

\section{Statistical analyses}

Weighted linear regressions, taking into account the number of herbarium specimens per year, were performed using the Stata software (StataCorp LP 2013) to examine the temporal correlations between leaf area values and growing degree-days. Two regression models were developed, one that accounts only for contemporaneous correlations, defined by $y_{t}=\alpha+x_{t} \beta+\varepsilon_{t}$ where $t$ is the time period, and another that accounts for a possible temporal lag (year -1$)$, defined by $y_{t}=\alpha+x_{t} \beta_{1}+x_{t-}$ ${ }_{1} \beta_{2}+\varepsilon_{t}$. For other analyses, leaf area data were log-transformed to normalize their distribution. A 
one-way ANOVA, using type III sums of squares for unbalanced design, was used to test for significant differences between herbarium specimens from different bioclimatic areas. ANOVAs were also used to test for differences in leaf area among the three different types of specimens (Table 1): (1) herbarium specimens, (2) modern specimens in sites without deer, and (3) modern specimens in sites with deer. To control for the unequal variance among the three specimen types (Bartlett test; $P<0.0001$ ), a variance weight was incorporated for specimen type using the varIdent function from the nlme package in R (Zuur et al. 2009; Pinheiro et al. 2013; R Core Team 2013). The heterogeneity of variance was controlled by allowing the residuals to vary for each nominal level of specimen type, i.e., three variance parameters estimated by the model (Zuur et al. 2009). To further test whether this heteroscedasticity was due to any site-specific effect in herbarium and modern data, a second model that incorporated a heterogeneous variance for each site, and a third model that incorporated both a heterogeneous variance for site and specimen type, were evaluated. The Akaike's information criterion (AIC) was used to compare these three models. The AIC is a measure of goodness-of-fit of the data to an estimated statistical model (Akaike 1974). The model with the smallest AIC value is considered the most appropriate (Legendre and Legendre 2012).

\section{Results}

There has been a significant rise in the number of growing degree-days for Southern Quebec over the last 100-150 years (Fig. 3), but no significant correlation (Table 2) was detected between growing degree-days data and white trillium leaf area values for the same period (Fig. 4). Moreover, no significant difference was found between herbarium specimens grouped according to their bioclimatic region (one-way ANOVA; $F_{2,689}=1.82, p=0.16$ ), suggesting no regional climate effect.

A significant effect of specimen type (herbarium vs. modern with deer vs. modern without deer) on leaf area was found (one-way ANOVA; $F_{2,3899}=379.23, p<0.0001$ ). However, heterogeneity of variance among sites was detected, essentially explained by the fact that one botanist sampled eight particularly small individuals at MRP 18 May 1932. This heterogeneity and potential bias - we 
cannot totally exclude the hypothesis that most individuals that emerged in 1932 were small - was controlled using a weighted variance for this factor; the second model, weighted for site, had the lowest AIC score (AIC for model 1: 39798.3; model 2: 39741.6; model 3: 39745.6).

In deer sites, white trillium populations were mostly (90\%) represented by flowering individuals with leaf area values $<90 \mathrm{~cm}^{2}$ (Figs. 5 and 6, Table 1), significantly lower than those of the herbarium specimens, and those of specimens collected in sites without deer $(p<0.001)$. Very few large individuals, i.e., with a leaf area $>130 \mathrm{~cm}^{2}$, persisted in deer sites. The distribution of white trillium individuals in deer sites was also skewed towards plants with a smaller leaf area, while the leaf area distribution included several very large individuals ( $>200 \mathrm{~cm}^{2}$; Figs. 5 and 6). However, herbarium specimens contained a greater proportion of small to very small individuals having a leaf area $15-55 \mathrm{~cm}^{2}$, than modern specimens in sites without deer.

\section{Discussion}

The herbarium specimens of white trillium were not specifically collected to study the impacts of deer browsing on leaf area. They nevertheless proved to be reliable tools for such purposes. The leaf area of modern individuals from sites with deer was significantly lower than that of modern specimens from sites without deer, which concurs with previous studies (Anderson 1994; Augustine and Frelich 1998; Knight 2003). The leaf area of modern specimens from sites with deer was also significantly lower than that of herbarium specimens, suggesting a size reduction over time. To what extent this size reduction is the result of an evolution-driven morphological change induced by deer browsing - smaller plants, less likely to be browsed, reproduce more successfully or by selective browsing mainly directed toward older and/or larger individuals - leaving only smaller individuals - remains to be determined. Other factors (soil nutrients, amount of sunlight reaching the plants, micro-climate differences, etc.) could also have been responsible for leaf area differences, but current knowledge on the disturbance dynamics of southern Quebec temperate forests (Beauvais et al. 2016), and previous studies conducted on the effect of white-tailed deer on 
white trillium (Anderson 1994; Augustine and Frelich 1998; Rooney and Waller 2001; Knight 2003; Knight et al. 2009), point toward deer browsing as the most important factor influencing leaf area.

Because most herbarium specimens were sampled before 1980 (85\%), i.e., before the rise of white-tailed deer populations in southern Quebec (Potvin 1994), they reflect very low deer density situations. Specimens sampled after 1980 were not significantly smaller than those sampled before 1980 , but this is not necessarily surprising because of the low number of recent specimens and the fact they were sampled in sites with various deer densities. Herbarium specimens can consequently be used as a reference population to determine the effect of deer on plant morphology on a regional basis, in combination with modern specimens. In southern Quebec, a significant reduction of leaf area of white trillium is likely driven by the expansion of deer populations, as other causes (e.g., climatic) have been ruled out.

Herbarium specimens of white trillium had similar leaf area values across bioclimatic regions, which suggests that the growth of this species is little influenced by climatic and environmental conditions, at least on a regional scale. This facilitates comparisons between sites, and increases the number of specimens that could be included in a reconstruction analysis, which in turn reduces the impacts of collecting biases (Lavoie 2013). Moreover, as shown in this study, gathering information on plant collectors is also important to detect (and correct) biases associated with botanists focusing on particular specimen types or sites (Lavoie et al. 2007).

The comparison of herbarium with modern specimens indicates that white trillium populations in deer sites are dominated by flowering individuals with a small leaf area, which likely have a lower reproductive success (Knight 2003). Particularly striking is the total absence, in forest sites with deer, of large individuals with a leaf area $>200 \mathrm{~cm}^{2}$. Although this absence is expected at high deer densities $\sim 25-35$ deer per $\mathrm{km}^{2}$ (Augustine and Frelich 1998), our study suggests that even densities as low as 8 deer per $\mathrm{km}^{2}$ can lead to the disappearance of a particular size class. The fact that very large specimens $>300 \mathrm{~cm}^{2}$ are found in herbaria, but were not found in nature, even in 
sites without deer, is also worrying, although the number of sites visited in 2013 and 2014 was relatively small. The exact contribution of these very large individuals to the long-term persistence of white trillium populations is unknown, but their absence clearly indicates an impoverishment of natural diversity and a skew toward smaller individuals with a lesser seed output.

In conclusion, herbarium specimens represent an inexpensive tool to assess the impact of large herbivores on plants, usually based on exclosures (Augustine and Frelich 1998; Webster et al. 2005) or on clipping experiments (Rooney and Waller 2001; Knight 2003; Knight 2007). The greatest potential of herbarium specimens is the spatial coverage, potentially continent-wide. Collecting herbarium specimens throughout the entire range of a species offers a much broader perspective on the impact of herbivores on plant fitness: specimens could be used to indicate where in the range meaningful changes occurred over time, a starting point for more detailed, in situ studies. Unfortunately, this possibility is seriously hampered by the decline of herbarium specimen collecting throughout North America (Prather et al. 2004; Lavoie and Lachance 2006; Lavoie et al. 2012). For example, the low number of records in Quebec after 1980, when the deer populations began to rise, limits herbarium collections to a reference database (low deer density), and additional field surveys are thus necessary to evaluate the impacts of browsing. Museum collections remain highly valuable, but their potential would be much greater if recent specimens were also available for comparison.

\section{Acknowledgements}

This research was financially supported by the Natural Sciences and Engineering Research Council of Canada, the Fonds de recherche du Québec Nature et Technologies, the Société des établissements de plein air du Québec and Les Amis du Jardin botanique de Montréal. The authors thank F. Beaulieu, A.A. Delorme and A. Langlois for field assistance, Z. Taranu for help with statistical analyses, N. Rivard and D. Rodrigue (Mont-Saint-Bruno National Park) for their continuous support during this project, and L. Gratton and D. Rodrigue for photographs. 


\section{References}

Akaike, H. 1974. A new look at the statistical model identification. IEEE Trans. Autom. Control. 19(6): 716-723. doi:10.1109/TAC.1974.1100705.

Anderson, R.C. 1994. Height of white-flowered trillium (Trillium grandiflorum) as an index of deer browsing intensity. Ecol. Appl. 4(1): 104-109. doi:10.2307/1942119.

Augustine, D.J., and Frelich, L.E. 1998. Effects of white-tailed deer on populations of an understory forb in fragmented deciduous forests. Conserv. Biol. 12(5): 995-1004. doi:10.1046/j.15231739.1998.97248.x.

Beauvais, M.-P., Pellerin, S., and Lavoie, C. 2016. Beta diversity declines while native plant species richness triples over 35 years in a suburban protected area. Biol. Conserv. 195(1): 73-81. doi.org/10.1016/j.biocon.2015.12.040.

Begley-Miller, D.R., Hipp, A.L., Brown, B.H., Hahn, M., and Rooney, T.P. 2014. White-tailed deer are a biotic filter during community assembly, reducing species and phylogenetic diversity. AoB Plants 6: plu030. doi:10.1093/aobpla/plu030.

Case, F.W., Jr., and Case, R.B. 1997. Trilliums. Timber Press, Portland, Oregon.

Centre d'enseignement et de recherche en foresterie de Sainte-Foy, and Institut national de la santé publique du Québec. 2012. Îlots de chaleur ou de fraicheur urbains. Available from http://geoegl.msp.gouv.qc.ca/gouvouvert/ [accessed 28 June 2016].

Collard, A., Lapointe, L., Ouellet, J.-P., Crête, M., Lussier, A., Daigle, C., and Côté, S.D. 2010. Slow responses of understory plants of maple-dominated forests to white-tailed deer experimental exclusion. For. Ecol. Manage. 260(5): 649-662. doi:10.1016/j.foreco.2010.05.021.

Côté, S.D., Rooney, T.P., Tremblay, J.-P., Dussault, C., and Waller, D.M. 2004. Ecological impacts of deer overabundance. Annu. Rev. Ecol. Evol. Syst. 35: 113-147. doi:10.1146/annurev.ecolsys.35.021103.105725. 
Delisle, F., Lavoie, C., Jean, M., and Lachance, D. 2003. Reconstructing the spread of invasive plants: taking into account biases associated with herbarium specimens. J. Biogeogr. 30(7): 1033-1042. doi:10.1046/j.1365-2699.2003.00897.x.

Government of Canada. 2016. Historical climate data. Available from http://climate.weather.gc.ca/ [accessed 28 June 2016].

Grandtner, M.M. 1966. La végétation forestière du Québec méridional. Les Presses de l’Université Laval, Québec, Quebec.

Gratton, L. 1981. Études floristique et phytosociologique du Mont Saint-Bruno. M.Sc. thesis, Département de biologie, Université du Québec à Montréal, Montréal, Quebec.

Guerin, G.R., Wen, H., and Lowe, A.J. 2012. Leaf morphology shift linked to climate change. Biol. Lett. 8: 882-886. doi:10.1098/rsbl.2012.0458.

Hanzawa, F.M., and Kalisz, S. 1993. The relationship between age, size, and reproduction in Trillium grandiflorum (Liliaceae). Am. J. Bot. 80(4): 405-410.

Hidding, B., Tremblay, J.-P., and Côté, S.D. 2012. Survival and growth of balsam fir seedlings and saplings under multiple controlled ungulate densities. For. Ecol. Manage. 276: 96-103. doi:10.1016/j.foreco.2012.03.023.

Horsley, S.B., Stout, S.L., and DeCalesta, D.S. 2003. White-tailed deer impact on the vegetation dynamics of a northern hardwood forest. Ecol. Appl. 13(1): 98-118. doi:10.1890/10510761(2003)013[0098:WTDIOT]2.0.CO;2.

Huot, J. 1973. Le cerf de Virginie au Québec. Ministère du Tourisme, de la Chasse et de la Pêche du Québec, Service de la Faune du Québec, Québec, Quebec.

Huot, M., and Lebel, F. 2012. Plan de gestion du cerf de Virginie au Québec 2010-2017. Ministère des Ressources naturelles et de la Faune du Québec, Secteur Faune Québec, Direction générale de l'expertise sur la faune et ses habitats, Québec, Quebec. 
Kalisz, S., Hanzawa, F.M., Tonsor, S.J., Thiede, D.A., and Voigt, S. 1999. Ant-mediated dispersal alters pattern of relatedness in a population of Trillium grandiflorum. Ecology 80(8): 2620-2634. doi:10.1890/0012-9658(1999)080[2620:AMSDAP]2.0.C0;2.

Knight, T.M. 2003. Effects of herbivory and its timing across populations of Trillium grandiflorum (Liliaceae). Am. J. Bot. 90(8): 1207-1214. doi:10.3732/ajb.90.8.1207.

Knight, T.M. 2007. Population-level consequences of herbivory timing in Trillium grandiflorum. Am. Midl. Nat. 157(1): 27-38. doi:http://dx.doi.org/10.1674/00030031(2007)157[27:PCOHTI]2.0.CO;2.

Knight, T.M., Barfield, M., and Holt, R.D. 2008. Evolutionary dynamics as a component of stagestructured matrix models: an example using Trillium grandiflorum. Am. Nat. 172(3): 375-392. doi:10.1086/589898.

Knight, T.M., Caswell, H., and Kalisz, S. 2009. Population growth rate of a common understory herb decreases non-linearly across a gradient of deer herbivory. For. Ecol. Manage. 257(3): 10951103. doi:10.1016/j.foreco.2008.11.018.

Lavoie, C. 2013. Biological collections in an ever changing world: herbaria as tools for biogeographical and environmental studies. Perspect. Plant Ecol. Evol. Syst. 15(1): 68-76. doi:10.1016/j.ppees.2012.10.002.

Lavoie, C., Jodoin, Y., and Goursaud de Merlis, A. 2007. How did common ragweed (Ambrosia artemisiifolia L.) spread in Québec? A historical analysis using herbarium records. J. Biogeogr. 34(10): 1751-1761. doi:10.1111/j.1365-2699.2007.01730.x.

Lavoie, C., and Lachance, D. 2006. A new herbarium-based method for reconstructing the phenology of plant species across large areas. Am. J. Bot. 93(4): 512-516. doi:10.3732/ajb.93.4.512.

Lavoie, C., Saint-Louis, A., Guay, G., Groeneveld, E., and Villeneuve, P. 2012. Naturalization of exotic plant species in north-eastern North America: trends and detection capacity. Divers. Distrib. 18(2): 180-190. doi:10.1111/j.1472-4642.2011.00826.x. 
Law, W., and Salick, J. 2005. Human-induced dwarfing of Himalayan snow lotus, Saussurea laniceps (Asteraceae). Proc. Natl. Acad. Sci. U.S.A. 102(29): 10218-10220. doi:10.1073/pnas.0502931102. Legendre, P., and Legendre, L. 2012. Numerical ecology. Elsevier, Amsterdam, Netherlands. Leger, E.A. 2013. Annual plants change in size over a century of observations. Glob. Change Biol. 19(7): 2229-2239. doi:10.1111/gcb.12208.

McGraw, J.B. 2001. Evidence for decline in stature of American ginseng plants from herbarium specimens. Biol. Conserv. 98(1): 25-32. doi:10.1016/S0006-3207(00)00138-5.

McGraw, J.B., and Furedi, M.A. 2005. Deer browsing and population viability of a forest understory plant. Science 307(5711): 920-922. doi:10.1126/science.1107036.

Nuttle, T., Royo, A.A., Adams, M.B., and Carson, W.P. 2013. Historic disturbance regimes promote tree diversity only under low browsing regimes in eastern deciduous forest. Ecol. Monogr. 83(1): 3-17. doi:10.1890/11-2263.1.

Pendergast, T.H. IV, Hanlon, S.M., Long, Z.M., Royo, A.A., and Carson, W.P. 2016. The legacy of deer overabundance: long-term delays in herbaceous understory recovery. Can. J. For. Res. 46(3): 362-369. doi.org/10.1139/cjfr-2015-0280.

Peppe, D.J., Royer, D.L., Cariglino, B., Oliver, S.Y., Newman, S., Leight, E., Enikolopov, G., FernandezBurgos, M., Herrera, F., Adams, J.M., Correa, E., Currano, E.D., Erickson, J.M., Hinojosa, L.F., Hoganson, J.W., Iglesias, A., Jaramillo, C.A., Johnson, K.R., Jordan, G.J., Kraft, N.J.B., Lovelock, E.C., Lusk, C.H., Niinemets, Ü., Peñuelas, J., Rapson, G., Wing, S.L., and Wright, I.J. 2011. Sensitivity of leaf size and shape to climate: global patterns and paleoclimatic applications. New Phytol. 190(3): 724-739. doi:10.1111/j.1469-8137.2010.03615.x.

Pinheiro, J.C., Bates, D., DebRoy, S., Sarkar, D., and R Development Core Team. 2013. nlme: linear and nonlinear mixed effects models. R package version 3.1-111. R Foundation for Statistical Computing, Vienna, Austria. 
Potvin, F. 1994. Plan de gestion du cerf de Virginie au Québec 1995-1999. Le système de suivi. Ministère de l'Environnement et de la Faune du Québec, Direction de la faune et des habitats, Québec, Quebec.

Prather, L.A., Alvarez-Fuentes, O., Mayfield, M.H., and Ferguson, C.J. 2004. The decline of plant collecting in the United States: a threat to the infrastructure of biodiversity studies. Syst. Bot. 29(1): 15-28. doi:http://dx.doi.org/10.1600/036364404772974185.

R Core Team. 2013. R: a language and environment for statistical computing. Version 3.0.2. R Foundation for Statistical Computing, Vienna, Austria.

Rooney, T.P., and Gross, K. 2003. A demographic study of deer browsing impacts on Trillium grandiflorum. Plant Ecol. 168(2): 267-277. doi:10.1023/A:1024486606698.

Rooney, T.P., and Waller, D.M. 2001. How experimental defoliation and leaf height affect growth and reproduction in Trillium grandiflorum. J. Torrey Bot. Soc. 128(4): 393-399.

StataCorp LP. 2013. Stata. Version 13.1. StataCorp LP, College Station, Texas.

Webster, C.R., and Jenkins, M.A. 2014. Evidence of long and discontinuous juvenile periods in Trillium catesbaei under contrasting levels of herbivory. Botany 92(1): 77-81. doi.org/10.1139/cjb-2013-0162.

Webster, C.R., Jenkins, M.A., and Rock, J.H. 2005. Long-term response of spring flora to chronic herbivory and deer exclusion in Great Smoky Mountains National Park, USA. Biol. Conserv. 125(3): 297-307. doi:10.1016/j.biocon.2005.03.027.

Zuur, A., Ieno, E.N., Walker, N., Saveliev, A.A., and Smith, G.M. 2009. Mixed effects models and extensions in ecology with R. Springer, New York, New York. 
Table 1. Modern and herbarium white trillium (Trillium grandiflorum) specimens used to evaluate the effects of white-tailed deer (Odocoileus virginianus) browsing on their leaf area over time and space in southern Quebec, Canada.

\begin{tabular}{|c|c|c|c|c|}
\hline Specimen type & $\begin{array}{l}\text { Sampling } \\
\text { years }\end{array}$ & $n$ & $\begin{array}{l}\text { Mean total leaf } \\
\text { area } \pm S D \\
\left(\mathrm{~cm}^{2}\right)\end{array}$ & $\begin{array}{l}\text { Deer density } \\
\left(n \text { per } \mathrm{km}^{2}\right)\end{array}$ \\
\hline \multicolumn{5}{|l|}{ Modern specimens } \\
\hline \multirow[t]{2}{*}{ Mont-Saint-Bruno National Park (MSB) } & 2013 & 489 & $65.6 \pm 24.9$ & 8 \\
\hline & 2014 & 202 & $54.0 \pm 20.7$ & 8 \\
\hline Fernand-Séguin Ecological Center (FSEC) & 2014 & 471 & $65.2 \pm 17.8$ & $>5$ \\
\hline Mont-Royal Park (MRP) & 2014 & 350 & $111.1 \pm 46.3$ & 0 \\
\hline \multirow[t]{2}{*}{ Montréal Botanical Garden (MBG) } & 2013 & 287 & $95.1 \pm 38.1$ & 0 \\
\hline & 2014 & 265 & $102.6 \pm 42.6$ & 0 \\
\hline \multicolumn{5}{|l|}{ Herbarium specimens } \\
\hline All specimens pooled & $1848-2011$ & 692 & $87.7 \pm 55.1$ & - \\
\hline Sugar maple - bitternut hickory region & $1848-2011$ & 597 & $86.3 \pm 55.6$ & - \\
\hline Island of Montréal & $1848-1997$ & 213 & $81.3 \pm 61.8$ & - \\
\hline $\begin{array}{l}\text { Monteregian hills others than Mont-Royal } \\
\text { Mont-Royal Park (MRP; without potential }\end{array}$ & & 198 & $90.7 \pm 50.4$ & - \\
\hline bias, see text for details) & $1874-1987$ & 65 & $76.9 \pm 49.4$ & - \\
\hline $\begin{array}{l}\text { Mont-Royal Park (MRP; potential bias } \\
\text { included, see text for details) }\end{array}$ & $1874-1987$ & 73 & $70.8 \pm 49.9$ & - \\
\hline
\end{tabular}


Table 2. Weighted linear regressions examining the temporal correlations (contemporaneous or year -1 ) between leaf area values (minimum, median, maximum) of herbarium white trillium (Trillium grandiflorum) specimens and growing degree-days collected in four meteorological stations from southern Quebec, Canada.

\begin{tabular}{|c|c|c|c|c|c|c|c|}
\hline \multirow[b]{2}{*}{ Station } & \multicolumn{2}{|c|}{ Minimum } & \multicolumn{2}{|c|}{ Median } & \multicolumn{2}{|c|}{ Maximum } & \multirow[b]{2}{*}{$\mathrm{T}($ size $)$} \\
\hline & $F$-stat & $p>F$ & $F$-stat & $p>F$ & $F$-stat & $p>F$ & \\
\hline \multicolumn{8}{|l|}{ Contemporaneous* } \\
\hline Drummondville & 1.04 & 0.3155 & 0.00 & 0.9490 & 0.41 & 0.5230 & 75 \\
\hline Les Cèdres & 0.38 & 0.5399 & 0.54 & 0.4641 & 0.44 & 0.5070 & 75 \\
\hline Montréal McGill University & 0.39 & 0.5319 & 0.00 & 0.9904 & 0.35 & 0.5580 & 74 \\
\hline Montréal Pierre-Elliott-Trudeau & & & & & & & \\
\hline International Airport & 1.07 & 0.3065 & 0.41 & 0.5246 & 0.22 & 0.6439 & 53 \\
\hline \multicolumn{8}{|l|}{ Year $-1^{* *}$} \\
\hline Drummondville & 0.69 & 0.5026 & 0.13 & 0.8776 & 0.79 & 0.4558 & 75 \\
\hline Les Cèdres & 0.23 & 0.7931 & 0.85 & 0.4330 & 0.30 & 0.7436 & 75 \\
\hline Montréal McGill University & 0.24 & 0.7931 & 0.41 & 0.6621 & 0.32 & 0.7270 & 74 \\
\hline Montréal Pierre-Elliott-Trudeau & & & & & & & \\
\hline International Airport & 0.66 & 0.5190 & 2.54 & 0.0890 & 0.18 & 0.8363 & 53 \\
\hline
\end{tabular}

${ }^{*}$ Model defined by $y_{t}=\alpha+x_{t} \beta+\varepsilon t$ where $t$ is the time period. F-test: $H_{0}: \beta=0$.

** Model defined by $y_{t}=\alpha+x_{t} \beta_{1}+x_{t-1} \beta_{2}+\varepsilon_{t}$ where $t$ is the time period. F-test: $H_{0}: \beta_{1}=\beta_{2}=0$. 


\section{Figure captions}

Fig. 1. Locations that were sampled in southern Quebec, Canada, for modern $(2013,2014)$ flowering specimens of white trillium (Trillium grandiflorum), and of the collection sites of the herbarium specimens with flowers used in this study. Modern specimen sampling sites: FSEC (Fernand-Séguin Ecological Center), MBG (Montréal Botanical Garden), MRP (Mont-Royal Park) and MSB (MontSaint-Bruno National Park). MBG and MRP are located on the Island of Montréal. The locations of the meteorological stations used in this study are also indicated: CED (Les Cèdres), DRU (Drummondville), MCG (Montréal McGill University) and PET (Montréal Pierre-Elliott-Trudeau International Airport). Gray area: Monteregian Hills region. Data source: original. Map created with: ArcGIS and Adobe Illustrator softwares.

Fig. 2. White trillium (Trillium grandiflorum) populations in the maple forests of Mont-Saint-Bruno National Park (Quebec, Canada), photographed in 1980 (L. Gratton; photograph used with permission), 1995 (D. Rodrigue; photograph used with permission), 2013 and 2014 (M.P. Beauvais). In 2013 and 2014, only a few flowering individuals remained (surrounded by a red circle). Although the photographs were not taken at the same location, they were deemed representative of the overall situation by park wardens $(1980,1995)$ or the authors $(2013,2014)$.

Fig. 3. Number of growing degree-days $\left(>0^{\circ} \mathrm{C} ; 1\right.$ January - 31 May) registered over time at four meteorological stations in Southern Quebec, Canada.

Fig. 4. Maximum, median and minimum leaf area of White trillium (Trillium grandiflorum) over time calculated from herbarium specimens collected in Southern Quebec, Canada.

Fig. 5. Distribution of leaf area of different types of specimens of white trillium (Trillium grandiflorum) from southern Quebec, Canada. For each boxplot, the median (horizontal bar), 25 and 
75 percentiles (box), 10 and 90 percentiles (error bars), and outlier values (circles) are indicated. Different letters indicate significant differences $(p<0.001)$.

Fig. 6. Cumulative frequency distributions of leaf area of different types of specimens of white trillium (Trillium grandiflorum) from southern Quebec, Canada. 


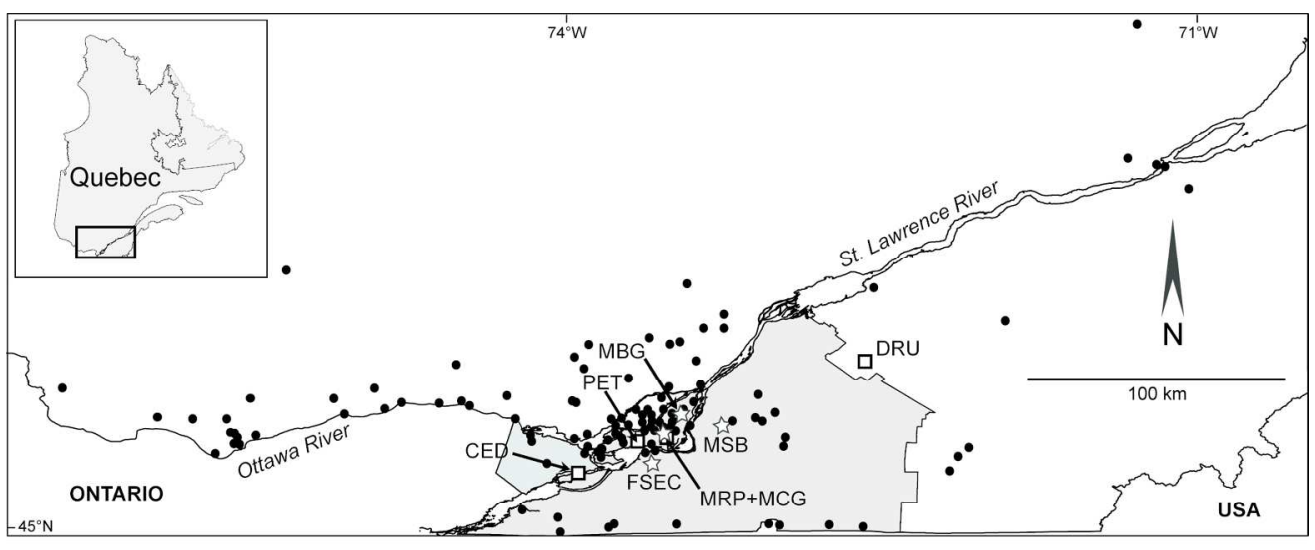

- HERBARIUM SPECIMEN SAMPLING SITE ¿̇ MODERN SPECIMEN SAMPLING SITE $\square$ METEOROLOGICAL STATION

Fig. 1. Locations that were sampled in southern Quebec, Canada, for modern $(2013,2014)$ flowering specimens of white trillium (Trillium grandiflorum), and of the collection sites of the herbarium specimens with flowers used in this study. Modern specimen sampling sites: FSEC (Fernand-Séguin Ecological Center), MBG (Montréal Botanical Garden), MRP (Mont-Royal Park) and MSB (Mont-Saint-Bruno National Park). MBG and MRP are located on the Island of Montréal. The locations of the meteorological stations used in this study are also indicated: CED (Les Cèdres), DRU (Drummondville), MCG (Montréal McGill University) and PET (Montréal Pierre-Elliott-Trudeau International Airport). Gray area: Monteregian Hills region. Data source: original. Map created with: ArcGIS and Adobe Illustrator softwares.

The modern white trillium popu $176 \times 83 \mathrm{~mm}(300 \times 300$ DPI $)$ 


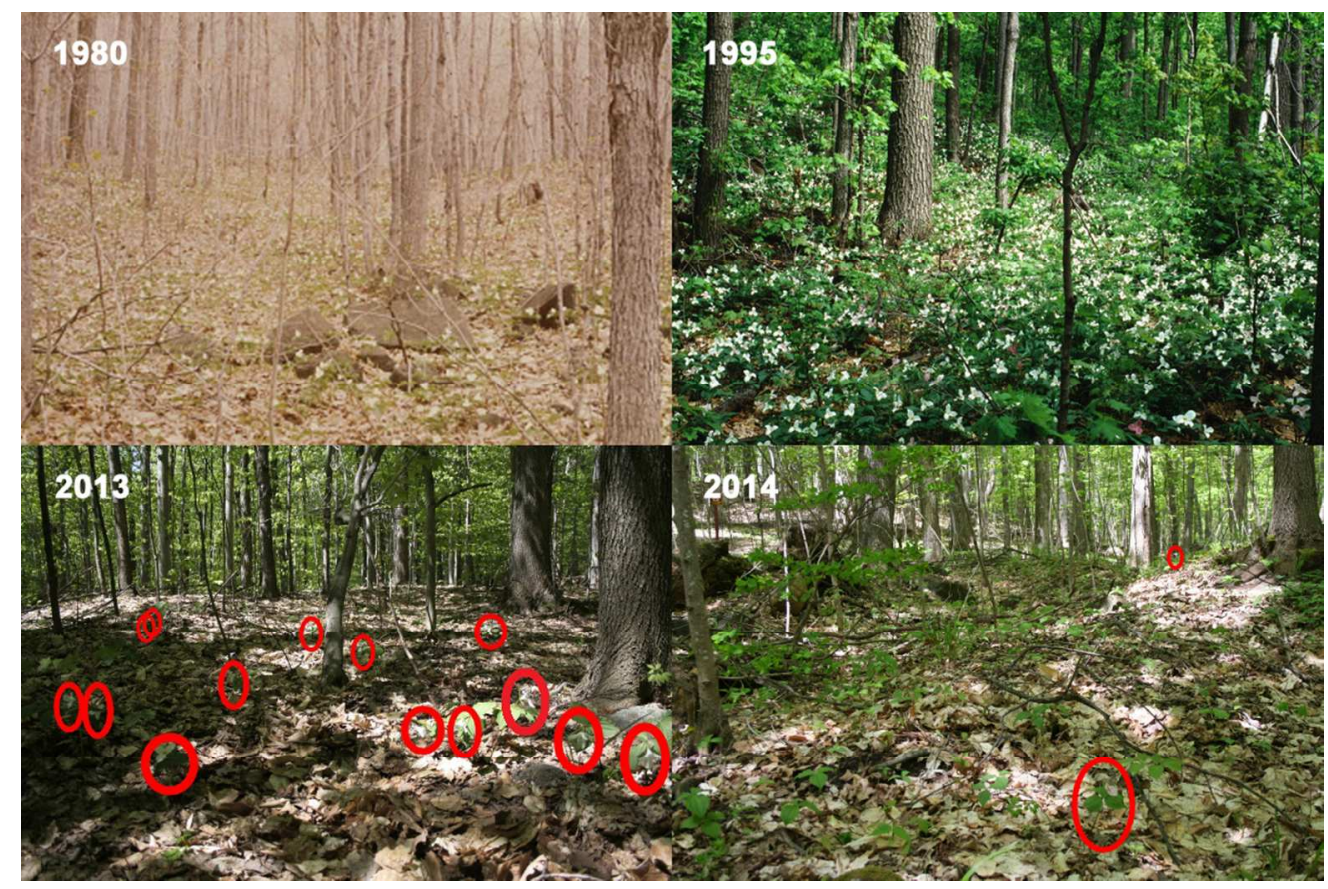

Fig. 2. White trillium (Trillium grandiflorum) populations in the maple forests of Mont-Saint-Bruno National Park (Quebec, Canada), photographed in 1980 (L. Gratton), 1995 (D. Rodrigue), 2013 and 2014 (M.-P. Beauvais). In 2013 and 2014, only a few flowering individuals remained (surrounded by a red circle). Although the photographs were not taken at the same location, they were deemed representative of the overall situation by park wardens $(1980,1995)$ or the authors $(2013,2014)$.

The modern white trillium popu 


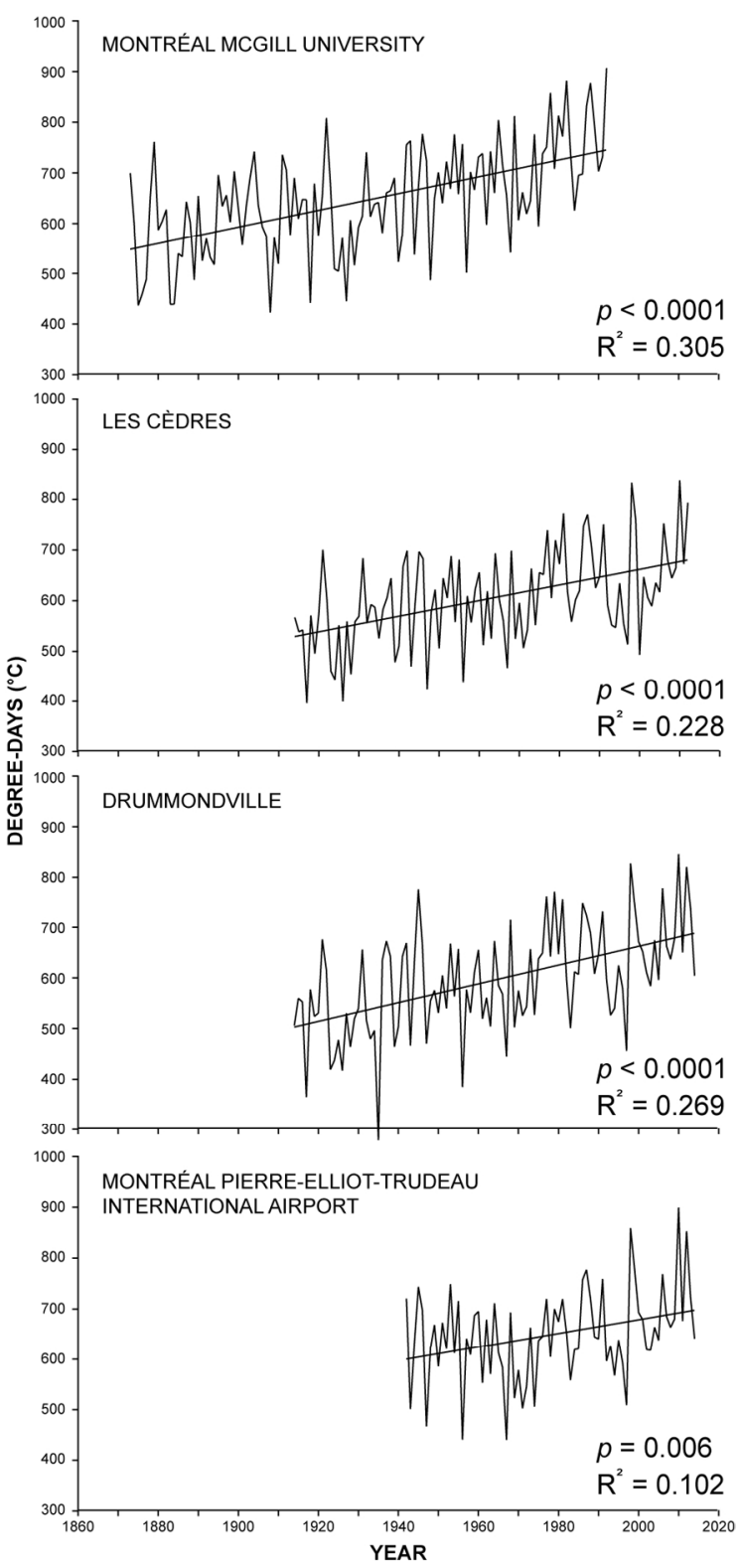

Fig. 3. Number of growing degree-days ( $>0^{\circ} \mathrm{C} ; 1$ January - 31 May) registered over time at four meteorological stations in Southern Quebec, Canada.

There has been a significant $r$ $83 \times 178 \mathrm{~mm}(300 \times 300 \mathrm{DPI})$ 


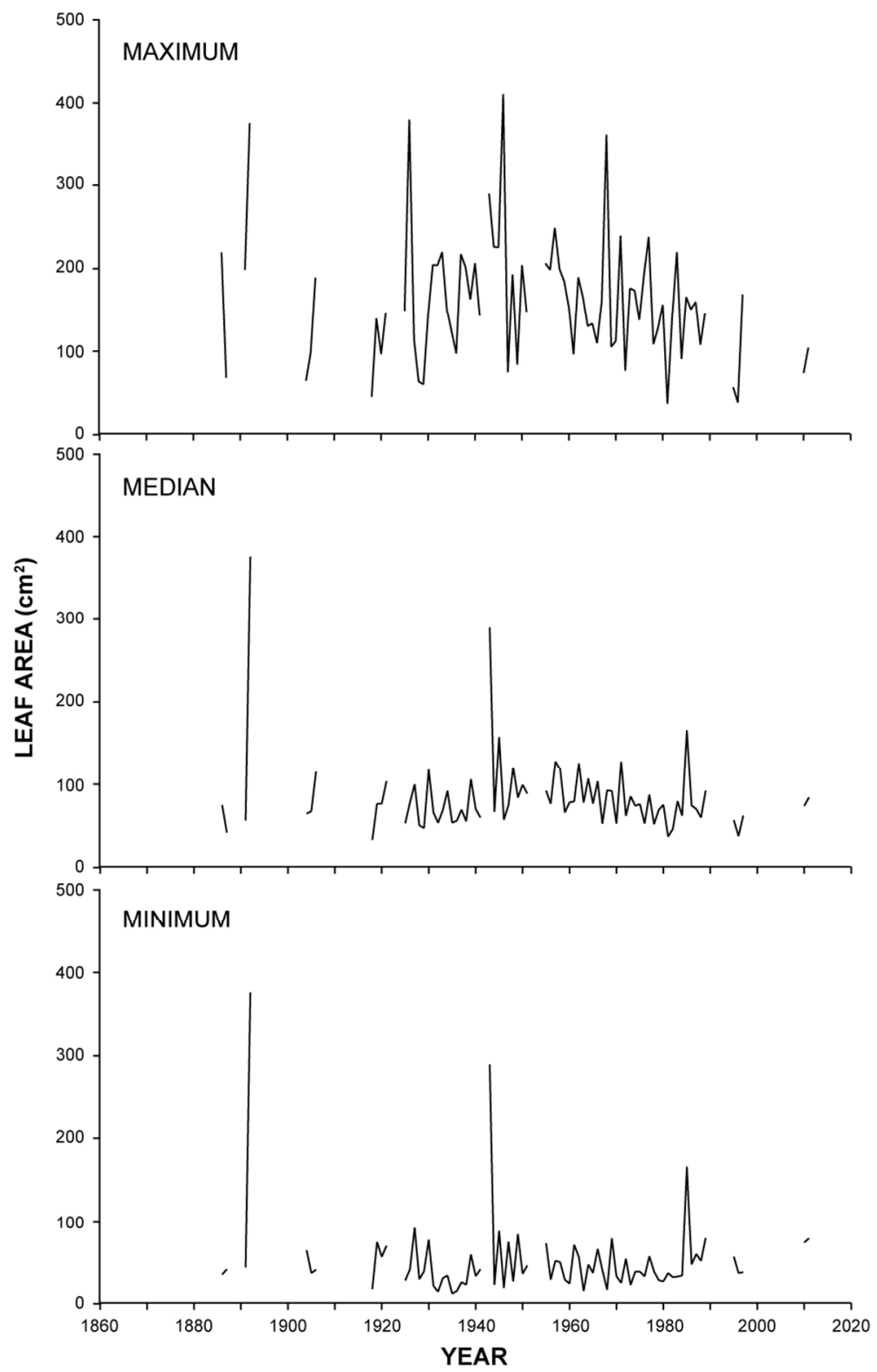

Fig. 4. Maximum, median and minimum leaf area of White trillium (Trillium grandiflorum) over time calculated from herbarium specimens collected in Southern Quebec, Canada. was detected between growing $\mathrm{d}$ $84 \times 133 \mathrm{~mm}(300 \times 300 \mathrm{DPI})$ 


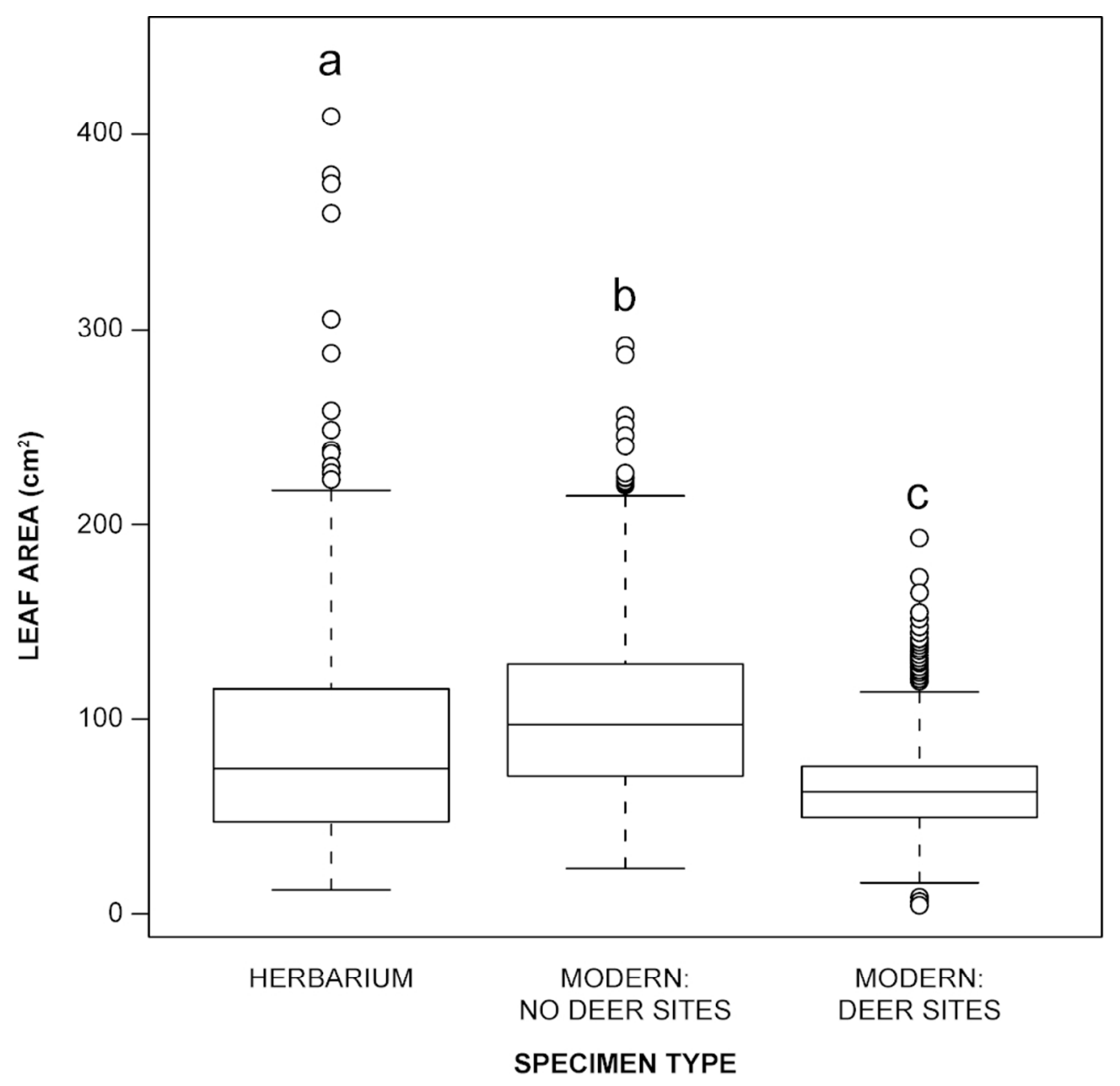

Fig. 5. Distribution of leaf area of different types of specimens of white trillium (Trillium grandiflorum) from southern Quebec, Canada. For each boxplot, the median (horizontal bar), 25 and 75 percentiles (box), 10 and 90 percentiles (error bars), and outlier values (circles) are indicated. Different letters indicate significant differences $(p<0.001)$.

In deer sites, white trillium

$84 \times 81 \mathrm{~mm}(300 \times 300 \mathrm{DPI})$ 


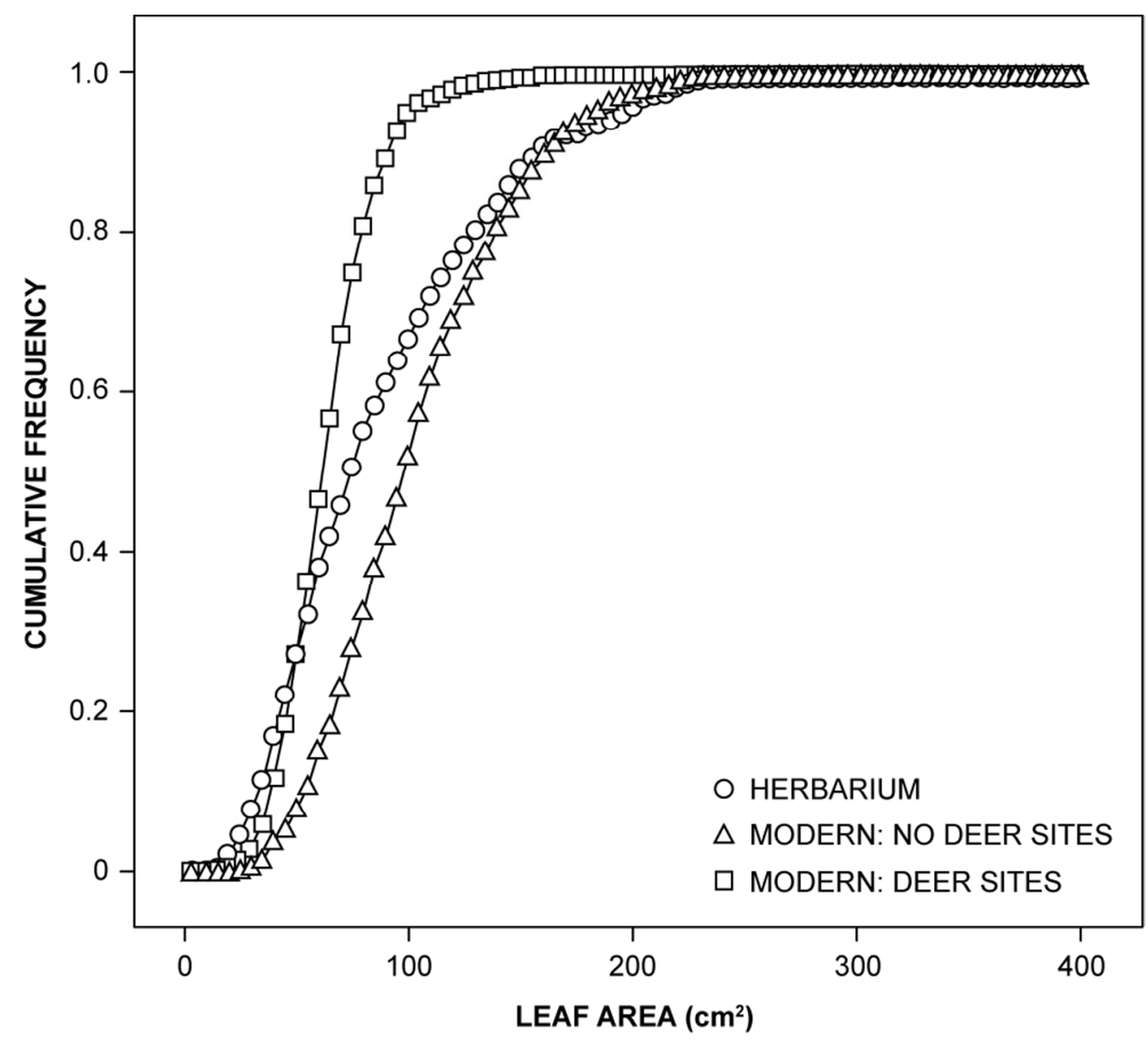

Fig. 6. Cumulative frequency distributions of leaf area of different types of specimens of white trillium (Trillium grandiflorum) from southern Quebec, Canada.

In deer sites, white trillium

$83 \times 75 \mathrm{~mm}(300 \times 300 \mathrm{DPI})$ 